Journal of American Studies, 49 (2015), 2, 305-32 I

(C) Cambridge University Press and British Association for American Studies 2015. This is an Open Access article, distributed under the terms of the Creative Commons AttributionNonCommercial-NoDerivatives licence (http://creativecommons.org/licenses/by-nc-nd/3.o/), which permits noncommercial re-use, distribution, and reproduction in any medium, provided the original work is unaltered and is properly cited. The written permission of Cambridge University Press must be obtained for commercial re-use or in order to create a derivative work. doi:10.1017/S0021875815000055

\title{
John Brown's Spirit: The Abolitionist Aesthetic of Emancipatory Martyrdom in Early Antilynching Protest Literature
}

\author{
ZOE TRODD
}

Before his execution in 1859 , the radical abolitionist John Brown wrote a series of prison letters that - along with his death itself - helped to cement the abolitionist aesthetic of emancipatory martyrdom. This article charts the adaptation of that aesthetic in antilynching protest literature during the decades that followed. It reveals Brown's own presence in antilynching speeches, sermons, articles, and fiction, and the endurance of the emancipatory martyr symbol that he helped to inaugurate. Between the i 88 os and the 1920 s, black and white writers imagined lynching's ritual violence as a crucifixion and drew upon the John Brown aesthetic of emancipatory martyrdom, including Frederick Douglass, Stephen Graham, James Weldon Johnson, Walter White, black Baptist ministers, and black educators and journalists. Fusing martyrdom and messianism, these antilynching writers made the black Christ of their texts an avenging liberatory angel. The testamentary body of this messianic martyr figure marks the nation for violent retribution. Turning the black Christ into a Brown-like prophetic sign of God's vengeful judgment, antilynching writers of the late nineteenth and early twentieth centuries warned of disaster, demanded a change of course, challenged white southern notions of redemption, and insisted that African Americans must reemancipate themselves and redeem the nation.

At midnight on 16 October I 859, the radical white abolitionist John Brown gave the order: "Men, get on your arms; we will proceed to the Ferry." With his interracial band of twenty-one men, he launched an attack against slavery and captured the town of Harpers Ferry, about sixty miles northwest of Washington, DC, intending that slaves use weapons from its arsenal to rise up and claim their freedom. Federal forces overwhelmed the band after thirty-six hours. Brown was taken to a Virginia jail cell and indicted on counts of murder, conspiracy, and treason. On 2 November he made his final address to the court and stood to hear his sentence. He would be publicly

American and Canadian Studies, University of Nottingham. Email: zoe.trodd@nottingham.ac.uk. 
hanged in Charles Town on 2 December. Brown returned to prison and asked the jailer, "Have you any objections to my writing to my wife and telling her that I am to be hanged ...?" That letter was one of more than a hundred that Brown wrote from his cell during the six-week period before his execution letters that turned his "forty days in prison" into "the mightiest Abolition document that America has known" (as W.E. B. Du Bois would later put it) and cemented the abolitionist aesthetic of emancipatory martyrdom. ${ }^{\mathrm{I}}$

Nearly six years later, in May I 865, the American Anti-slavery Society (AASS) held its thirty-second annual meeting. The Civil War was over and Congress had passed the $13^{\text {th }}$ Amendment. William Lloyd Garrison was ready to disband the society and proposed a dissolution resolution. But Frederick Douglass, Wendell Phillips, and others disagreed. In a prophetic speech of 28 December I 862, Douglass had warned that Emancipation would not wipe out slavery's spirit. The institution had "stamped its character too deeply and indelibly, to be blotted out in a day or a year, or even a generation," he observed. This was "no time for the friends of freedom to fold their hands and consider their work at an end." Now, debating the dissolution of these "friends of freedom," Douglass observed that true emancipation meant giving African Americans the ballot and ending segregation. He warned that slavery could yet "call itself by yet another name" and that abolitionists should wait to see "in what new skin this old snake will come forth next." After two days of debate, Garrison's resolution was defeated by a vote of I 8 to 48 . Garrison withdrew from the society and Phillips took over as president. ${ }^{2}$

Five years later, in April I 870, the AASS met again. The I 5 th Amendment had been ratified and the abolitionists considered another resolution to dissolve their society. This time, Douglass and Phillips were in favor. Douglass celebrated the society's accomplishments and expressed no regret at its discontinuance. Phillips believed that abolitionists should throw their exertions "into channels more fitting the hour." Other abolition societies were going the same way. The Massachusetts Anti-slavery Society had disbanded in January I 870. The Philadelphia Female Anti-slavery Society had held its final meeting in March and the Pennsylvania Anti-slavery Society would be disbanded in May. Gilbert Haven, Stephen Foster, and Cora Daniels Tappan still resisted

I John Brown quoted in W. E. B. Du Bois, John Brown (Philadelphia: G. W. Jacobs, 1909), 308; Brown quoted in Oswald Garrison Villard, John Brown, I800-1859: A Biography Fifty Years After (Boston: Houghton Mifflin, I 910 ), 545; Du Bois, 365.

2 Frederick Douglass, "A Day for Poetry and Song," Douglass' Monthly, Jan. I 863, 770; Douglass, "The Need for Continuing Anti-slavery Work," 9 May I865, in Philip S. Foner (ed.), The Life and Writings of Frederick Douglass (New York: International Publishers, 1950-55), Volume IV, 169. 
dissolution of the AASS (Foster suggesting that they retain the society in fact if not in form and continue their work under a new name). Haven had recently proclaimed that although God chastised the country with the Civil War, the ghosts of the rebel fighters now rode through the land in the form of the $\mathrm{Ku}$ Klux Klan. The "spirit of slavery" had risen from its "unquiet" grave, Haven observed. Nonetheless the society issued a declaration titled "The Fulfillment of Our Pledge," proclaiming that its anti-slavery work was complete. ${ }^{3}$

Less than a decade later, Douglass was forced to acknowledge that the abolitionists' work was far from over. The South's last Republican governments fell in 1877 , federal troops withdrew from the region, and redeemer governments began to roll back the gains of Reconstruction and reestablish white-supremacist rule in the old Confederate states. In June I 879, a week after Garrison's death, Douglass saw a "second battle for liberty" unfolding. A "spirit of evil has been revived which we had fondly hoped was laid forever," he observed. The nation had only "half learned" the "lessons" taught by abolitionists and so the abolitionist "army" would have to "march on." By the r 880 s, Douglass was vehemently protesting the nation's broken promises. The "old master class" was triumphing over newly enfranchised black citizens through lynch law, he exclaimed in I 880 . He argued in I 888 that "though [the Negro] is nominally free he is actually a slave." Terming "so-called emancipation" a "stupendous fraud," he noted that peonage, disfranchisement, and lynching meant that there was "more cause for alarm" than at any moment since the abolition of slavery. He prophesied that there would be another war, to reabolish slavery, unless injustice, oppression, and cruelty were banished from the South immediately. His task, he said, was to "[c]ry aloud and spare not," because African Americans were "bound to keep fresh a memory of the past till justice shall be done them in the present," even as the rest of the nation tried to forget slavery. ${ }^{4}$

3 "Report on the Commemorative Meeting of the American Anti-slavery Society, April 9," National Anti-Slavery Standard, 16 April 1870, I-3; Gilbert Haven, "America's Past and Future" (26 Nov. 1868), in Haven, National Sermons (Boston: Lee and Shepard, 1869), 603-20, 6II, 618.

4 Douglass, "Speech on the Death of Garrison," 2 June 1879 , in the Frederick Douglass Papers, Manuscript Division, Library of Congress (hereafter FDP), Box 23, Reel i 5; Douglass, "The Lessons of Emancipation to the New Generation," 3 Aug. I 880, in John Blassingame and John McKivigan (eds.), The Frederick Douglass Papers: Series One (New Haven: Yale University Press, 1991), Volume IV, 565; Douglass, "I Denounce the So-Called Emancipation as a Stupendous Fraud," I6 April 1888, in Philip S. Foner and Yuval Taylor (eds.), Frederick Douglass: Selected Speeches and Writings (Chicago: Lawrence Hill Books, 1999), 7I2-24, 7I2, 713, 715. By the time of Douglass's 1888 speech, the Tuskegee Institute had begun gathering statistics on lynching. It recorded 4,743 lynchings between 1882 and 1968. Of these victims, it listed 3,446 as black men and women. There were a record 230 lynchings in 1892 , then 97 in 1908 and 83 in 1919. 
Douglass's use of the prophetic voice to warn the nation of catastrophe unless it changed course, and his proclamation that remembering the past was necessary to seek justice in the present, form the key elements of an antilynching jeremiad in protest literature after Emancipation. Antilynching activists and writers recognized that the old snake of slavery had come forth in a new skin, as Douglass had warned in 1865 at the AASS meeting. They declared lynching a revival of slavery's spirit, as Douglass put it in 1879 . They imagined their post-Reconstruction activism as a renewal of abolitionism and, like Douglass, they cried aloud and spared not. Seeing lynching as a religiously justified attempt to reverse Emancipation - to redeem the South after its loss in the Civil War - antilynching writers and activists developed a counterrhetoric: they recognized lynching as a Christian ritual and put a black Christ at the ritual's center. If the lynch victim was the South's scapegoat, then antilynching writers would transform the scapegoat into a martyr.

Turning racial redemption on its head, they imagined lynching's ritual violence as a crucifixion and drew upon the John Brown aesthetic of emancipatory martyrdom. The black Christ of antilynching literature offers no forgiveness. Not patient or long-suffering, he is the armed Christ of the book of Revelations, a militant Christ fighting a holy war for black emancipation. Fusing martyrdom and messianism, antilynching writers made the crucified Christ an avenging liberatory angel. Like Brown, this black Christ of antilynching is a prophetic sign of God's vengeful judgment. His testamentary body marks the nation for violent retribution. Making the black Christ the centerpiece of their jeremiad, antilynching writers of the late nineteenth and early twentieth centuries used the messianic martyr figure to warn of disaster, demand a change of course, and challenge white southern notions of redemption with a black messianic belief that African Americans must reemancipate themselves and redeem the nation.

\section{ABOLITIONISM'S EMANCIPATORY MARTYRDOM}

John Brown's prison letters were ostensibly private, addressed to his family, friends, and acquaintances. But within the context of a thriving abolitionist print culture, aided by the daily and extensive press coverage of his raid, trial, and execution, most of the letters were published in northern newspapers (including the New York Tribune, which had the largest circulation of any American newspaper at the time). Widely read, Brown's prison letters shaped public perception of his raid. Across the North, derision turned to praise, and in the South, journalists' contemptuous dismissals gave way to warnings that Brown was a portentous omen. In fact, Brown himself wrote the letters for a dual audience: his inner circle and the newspaper-reading public. He used them to enter the Judeo-Christian tradition's pantheon of 
saints and martyrs, making his raid a sacred text that was ripe for prophetic readings and interpretative action.

The scaffold may have been a "manner of dying assigned" to him, as he acknowledges in one letter, but he could shape the meaning of that death. $\mathrm{He}$ insists in other letters that he was "worth inconceivably more to hang than for any other purpose" for "in no other possible way could I be used to so much advantage to the cause of God." Echoing scenes in popular sentimental fiction, he proclaims, "Eternal life is what my soul is panting after." $\mathrm{He}$ intends to die for the nation's soul and even explicitly connected his own labor to that of God's prophets, instructing his family to remember that Christ "suffered a most excruciating death on the cross as a felon" and that Brown shares the fate of "prophets and apostles and Christians of former days." In another letter, he includes an unacknowledged quotation from Jesus on the cross: "I think I feel as happy as Paul did when he lay in prison. He knew if they killed him, it would greatly advance the cause of Christ ... Let them hang me; I forgive them, and may God forgive them, for they know not what they do." Joining social critique to spiritual renewal, Brown offered himself as a biblical character. ${ }^{5}$

This self-fashioning allowed abolitionists to repackage Brown's actions for their cause. Theodore Parker believed that Brown would die "like a martyr," explaining on 24 November that this would "make a profound impression." Meanwhile, Henry Ward Beecher announced in a sermon, "Let Virginia make him a martyr. Now, he has only blundered ... a cord and a gibbet would redeem all that." Even before his death, ministers sermonized Brown into the tradition of Saint Stephen, Saint Paul, and John the Baptist. Others took up Brown's own comparisons to Christ. Frederick Frothingham saw Brown's death slaying the sin of slavery, just as Christ's death had slain all sin. Henry David Thoreau called Brown's actions a "sublime spectacle" and observed that Christ's crucifixion and Brown's execution were "two ends" of a linked chain. Ralph Waldo Emerson agreed. He borrowed the words of his friend Mattie Griffith, referring to Brown as "the new saint" who "will make the gallows glorious like the cross." 6

Yet, not only depicting himself as a Christ-like martyr, Brown also used the imagery of the Old Testament. Balancing his Christ-like persona with images of righteous retribution, he compared himself to Daniel and Samson on is

5 John Brown, prison letters, in John Stauffer and Zoe Trodd (eds.), The Tribunal: Responses to John Brown and the Harpers Ferry Raid (Cambridge, MA: Harvard University Press, 2012), 69, 6I, 71, 72, 59, 66.

${ }^{6}$ Theodore Parker and Henry Ward Beecher in Stauffer and Trodd, 136, 104; Frederick Frothingham, "The Harpers Ferry Tragedy: A Discourse," The Liberator, 30 Dec. 1859, 4; Henry David Thoreau and Ralph Waldo Emerson in Stauffer and Trodd, I08, I09, I 14. 
November and to Moses on 25 November. Speaking in the prophetic voice, he described the moment as a dark night and a "furious and dreadful" storm that was preventing "the return of warm sunshine and a cloudless sky," but said he foresaw disaster becoming "the most glorious success." In another letter he promised that God would "overrule all for his glory." Abolitionists picked up this Old Testament thread of the John Brown story too. Douglass noted that Brown, like Samson, had "laid his hands upon the pillars of this great national temple of cruelty and blood" and that "when he falls, that temple will speedily crumble to its final doom." Elsewhere Douglass described Brown as an American Moses, as did Osborne Anderson, one of Brown's black raiders, who claimed in I86I, "there is an unbroken chain of sentiment and purpose from Moses of the Jews to John Brown of America." 7

For Brown, there was no contradiction between the Old Testament God of war and the New Testament suffering Christ. And so, alongside his embrace of the Old Testament warrior God, he also embraced the soldier Christ of Revelations. He described himself as a new Moses, sent by God to "deliver Israel out of the hand of the Philistines," and also a man "armed" by Christ with a "sword" and fighting for "Christ the great Captain of liberty" as a "faithful soldier." God was "wise and merciful" but also "just and holy," he emphasized to his family in one letter, and so Brown could be a gentle martyr and a holy warrior at the same time. ${ }^{8}$

Numerous abolitionists echoed this strategy of blending Calvary and Revelations as they responded to Brown's raid and death in late I 859 and I 860. They blended images of martyrdom and apocalyptic violence, like Brown, to suggest that his death was the beginning of a divine judgment his martyrdom a door to the millennium. Edwin Wheelock even fused biblical figures into a single statement: "The bondman has stood face to face with his Moses. The Christ of anti-slavery has sent forth its 'John," he observed. In Wheelock's sermon, Brown is both the "first Plague launched by Jehovah" and a sacrificial lamb whose blood will bring the "temporal salvation of four millions of our people." Fales Henry Newhall performed a similar fusion of martyrdom and apocalyptic millennialism. Brown has "consecrated the gibbet" just as Christ made the cross "glorious," but is also "Samson of Osawatomie" who topples the pillars of slavery so that America hears a "great crash." For James Redpath, Brown was both a martyr who "died for his country" and a "Man of War." And for numerous poets who published verse in The Liberator and elsewhere after Brown's death, there was no

\footnotetext{
7 Brown, prison letters, in Stauffer and Trodd, 60, 71, 57; Douglass and Osborne Anderson in Stauffer and Trodd, i i $9,229$.

${ }^{8}$ Brown, prison letters, in Stauffer and Trodd, 67, 62, 71 .
} 
contradiction between Brown as long-suffering Christ and Brown as avenging angel. J. T. Powers called Brown the "bondman's Savior" but also imagined his blood as a "holy sea," swallowing America's Pharaohs. Joseph A. Horner described Brown's martyrdom as a catalyst for "the fight," and in Robert Henry Newell's "Avenged" Brown wears a "martyr's Crown" and fights with "Soldier's steel." Then, once the war began, poets imagined it as an apocalypse brought on by Brown's martyrdom. Benjamin H. Clark called Brown's gallows tree a new cross that generated a "day of righteous wrath/On Tyranny" and F. B. Gage explained that God the "avenger" was blasting the region where Brown's "glorious martyrdom" took place."

In blending images of Christ's crucifixion and divine vengeance, abolitionists suggested that Brown's martyrdom brought no guaranteed redemption only God's wrath until America redeemed itself by ending slavery. Here, Brown had helped them by articulating this message himself. He offered in his letters a premillennialist vision whereby God's kingdom on Earth would be preceded by apocalyptic violence and the shedding of blood. Knowing that change would not come without human action, his raid had been a radical interpretation of the Bible and an effort to help God in His cause. Then, after interpreting the Bible with his raid and in his letters, Brown interpreted his raid as a call to further action.

In fact, Brown's letters not only opened up his raid as a text for interpretation, but also contained a guide to that interpretative process. He made himself an example, exhorting his readers in one letter "to remember and follow my advice, and my example too, so far as it has been consistent with the holy religion of Jesus Christ." Even more importantly, he judged his own actions as the first bloodshed of a larger conflict. As dawn broke eon 2 December, he handed his last letter to a prison guard. A mere two sentences, it read,

I John Brown am now quite certain that the crimes of this guilty land will never be purged away; but with Blood. I had as I now think; vainly flattered myself that without very much bloodshed; it might be done.

"Blood" referred to the bloodshed of his raid, of his execution, and of the conflict over slavery that Brown knew lay ahead. The bloodshed of his

9 Edwin M. Wheelock in James Redpath, Echoes of Harper's Ferry (Boston: Thayer and Eldridge, 1860), 177-78, 179, 191; Fales Henry Newhall in Stauffer and Trodd, 168, I69; James Redpath, "Dedication" and "Preface" in Redpath, 4, 9; J. T. Powers, "Freedom, Dedicated to the Martyr Brown," The Liberator, I3 April i860, 4; Joseph A. Horner, "John Brown," The Liberator, I3 April I860, 4; Robert Henry Newell, "Avenged!", in Newell, The Orpheus C. Kerr Papers, Second Series (New York: Carleton, I 863), 24I-46, 244; Benjamin H. Clark, "John Brown Avenged," The Liberator, 27 June I 862, 4; F. B. Gage, "John Brown's Avenger," The Liberator, 9 Jan. I863, 4. 
execution, connecting that of his raid and of the future conflict, made inevitable more bloodshed. He was performing an emancipatory martyrdom, offering his body on the gallows as the bridge to a redeemed nation that others might cross. Intended to sow further seeds of sectional discord and help push the nation past the point of accommodation and compromise, Brown's scripture contained his prophecies and attempted to assist their fulfilment. He would be a portent but also a catalyst - part of the route to emancipation. ${ }^{\circ}$

Heeding Brown's guide to his proffered scripture, abolitionists used his raid and death to prepare the country for slavery's divinely approved end. "John Brown has loosened the roots of the slave system," proclaimed Wendell Phillips at Brown's funeral. The system's extinction was just a matter of time: "It only breathes - it does not live hereafter." Participants at a commemorative meeting in Vermont, on 2 December, resolved that Brown's executioners were like Christ's crucifiers and that "as the blood of the martyrs is the seed of the church, so the death of Capt. Brown will intensify the "irrepressible conflict' and hasten the downfall of the slave power." Gilbert Haven called Brown's raid a "new act" in the "great drama of the rights and destiny of humanity" and hoped it might be understood as a divine warning, thereby prompting emancipation: "The terrors of the Lord have persuaded multitudes of men to be holy ... May we not hope that ... dread of the just vengeance of their oppressed brethren, will persuade them to give them that which is just and equal?" George Cheever sounded an even more urgent warning. Brown was Moses, throwing down his rod before an American Egypt, and this meant that deadly plagues would follow, he said. Then, in true prophetic style, Cheever offered America the chance to avoid such destruction: "God shows us the coming evil ... We may avoid it, but there is only one way ... by immediate repentance, and renunciation of the sin." He went on to explain that "repentance" meant the immediate emancipation of slaves. The next month, Cheever was still warning the country that Brown's death was the beginning of the end. That end could be a "peaceful emancipation of the slaves" or "a whirlwind of the Divine vengeance," the choice was America's. For these abolitionists, Brown's performance of emancipatory martyrdom demanded responsive audience members. ${ }^{\text {I }}$

Brown had reenacted both Christ's crucifixion and God's judgment of Egypt, and abolitionists recognized both processes. Some believed that Brown had performed this emancipatory martyrdom so clearly that his

${ }^{10}$ Brown, prison letters, in Stauffer and Trodd, 57, 73.

${ }^{11}$ Wendell Phillips in Stauffer and Trodd, 175 ; "John Brown Commemoration Meeting," The Liberator, I 3 Jan. I860, 4; Gilbert Haven and George Cheever in Redpath, I 25, I 29, I 54, I6I, 235 . 
legacy was secure. Proclaiming the Civil War a fulfilment of Brown's prophecies, Douglass observed in January 1862 that Brown looked down and saw his murderers suffering the "torments of their own kindling." Surrounded by an army of martyrs and saints, Brown saw "the faith for which he nobly died steadily becoming the saving faith of the nation." Douglass also explained that Americans were finally learning the abolitionists' long-urged lesson through the "earthquake" of war: "persistent transgressions of the laws of this Divine government will certainly bring national sorrow, shame, suffering and death." Like other abolitionists, he saw the Civil War in apocalyptic terms, as a struggle that would birth a new age. Promising free black men that the "day dawns," he called them to the Union ranks: "Remember Shields Green and Copeland, who followed John Brown, and fell as glorious martyrs." Those before them had fallen as martyrs to the abolitionist cause; now black troops must complete the work of ushering in the millennium through emancipatory martyrdom. ${ }^{12}$

But it was not long before Douglass acknowledged that the apocalypse had brought no millennium. He began to protest lynching as a revival of slavery's spirit and he sought a revival of the abolitionist spirit in response. America still needed its John Browns, Douglass observed after discussing lynching in I 886. He hoped "some great man will arise and do for us in this new emergency what was done against our slavery" so that deliverance would finally come. Fearing that America had not grasped the true meaning of Brown's death, he wondered in I88I if the country stood "too near the days of slavery ... to see clearly the true martyr and hero that he was." Perhaps, Douglass suggested, like all "men born in advance of their times, the men whose bleeding footprints attest the immense cost of reform ... this our noblest American hero must wait the polishing wheels of after-coming centuries to make his glory more manifest." As America rejected, again, the abolitionist lesson, perhaps only the future's polishing wheels would fully reveal Brown's sublimity. ${ }^{13}$

\section{EARLY ANTILYNCHING'S ABOLITIONIST AESTHETICS}

Sure enough, one set of "polishing wheels" spun throughout the antilynching movement - of which Douglass was part. In the I880s and i 890 os Douglass revived the abolitionist jeremiad, writing numerous speeches and articles that traced lynching's origins to slavery and debunked the white-supremacist

${ }^{12}$ Frederick Douglass, "Speech on the War," Douglass' Monthly, Feb. 1 862, 597; Douglass, "The Proclamation," Douglass' Monthly, March i 863, 805; Douglass, "Men of Color, to Arms," Douglass' Monthly, March i 863, 80 I.

${ }^{13}$ Douglass, letter to Francis J. Grimké, I9 Jan. 1886, in Foner and Taylor, 695; Douglass in Stauffer and Trodd, 497. 
notion that lynching was a necessary response to rape. The "hell-black outrages" of lynching proved that the nation still lingered "in the shadow and blight of an extinct institution," he proclaimed in 1883 . Three years later, he wondered why the same army that hunted slaves and suppressed slave insurrections could not be used to suppress lynching. "There is no blood so cheap as the negro's blood," he concluded; "I have been saying these things to the American people for nearly fifty years." In the early I 890 os he repeated that slavery's "asserted spirit" was prevailing. Slaves were "branded with hot irons, loaded with chains, and whipped to death with impunity" and southerners can murder today without even sustaining "a loss of property." By the I 890s, Douglass was also returning to his prewar imagery of divinely sanctioned vengeance. Just as slavery cost America "a million graves," so lynching "may yet bring vengeance," he warned in his last great public speech. In an article he added that when "men sow the wind it is rational to expect that they will reap the whirlwind." That whirlwind might look the same as in I 859. Black men had joined Brown at Harpers Ferry and "care should be taken" that they do not take up arms against lynching today, Douglass added. ${ }^{14}$

Douglass died on 20 February I 895. Between 2 I February and mid-April groups of people met in churches and chapels, schools and colleges, club houses and town halls, to hold memorial exercises and adopt resolutions. One group used Douglass's death to declare that antilynching agitation must continue. Black citizens of Sumter County, Georgia held a mass meeting on 27 February I 895. Their resolutions praise Douglass's “withering philippics" against lynching but conclude that the battle was not yet won. His "struggles" and "achievements" would be the race's "standard" and "inspiration." Like Douglass himself, the Georgia group saw abolitionism as a usable protest past. And in fact, like Douglass, numerous writers and activists reshaped the abolitionist jeremiad into an antilynching politics of form. They recognized lynching as part of the Lost Cause civil religion and reintroduced the emancipatory martyr into this cosmic drama. Transforming lynching into both a crucifixion and an inauguration of the apocalypse, while remembering John Brown's martyrdom, they used lynch-crucifixions to warn of another

${ }^{14}$ Frederick Douglass, "Address to the People of the United States," 25 Sept. 1883, in Douglass, Three Addresses on the Relations Subsisting between the White and Colored People of the United States (Washington, DC: Gibson Bros., 1886), 9, 8; Douglass, "Address Delivered on the Occasion of the Twenty-Fourth Anniversary of the Abolition of Slavery," I6 April 1886, in Douglass, Three Addresses, 67; Douglass, introduction to The Reason Why the Colored American Is Not in the World's Columbian Exposition (Chicago: Ida B. Wells, I893), 9, I I; Douglass, "Lynch Law in the South," North American Review, July I 892, I 9; Douglass, "A Defence of the Negro Race" (1894), FDP, Box 26, Reel 17; Douglass, The Lessons of the Hour (Baltimore: Press of Thomas \& Evans, I 894), 32; Douglass, "Lynch Law in the South," 22, 23. 
divine judgment if the nation continued to reject Emancipation's proffered millennium. ${ }^{\text {is }}$

This abolitionist jeremiad for antilynching began in the I 880 s and I 890 s, when black ministers - along with Douglass - pioneered the notion that the sin of lynching would be punished by another national calamity and explicitly summoned their protest forebears. By the i 890 s, it was rare for an antilynching sermon to forgo the overlapping themes of abolitionism and the biblical apocalypse. In I 890, Robert A. McGuinn, a Baptist minister in Maryland, described lynching as southern white "vengeance" for Emancipation and summoned the abolitionists as God's avengers. He concluded that "a slain and persecuted people will be heard" and the "oppressor always has to atone." Emmanuel King Love, a Baptist leader in Georgia, developed this idea of abolitionist vengeance for lynching. His Emancipation Day oration for 1891 described the "old disease" of slavery returning in a "malignant form": "the burning of human beings alive." But after protesting the "lawless" slaughtering of black people, he reminded his audience that slavery perished in a "sea of blood." These "historical hints" mean that another "catastrophe" is coming - for God will "avenge" southern cruelty again. Quoting a nautical metaphor from Douglass to imagine black citizens finding a "life boat" in this "angry sea," Love promised that God would avenge lynching and finish what $\mathrm{He}$ began in abolitionism. Love repeated this warning in 1893 , promising that the biblical drama of lynching would have the same ending as the biblical drama of American slavery. A "day of retribution" answered slavery and the same "just God" would give a "bloody answering" for lynching. ${ }^{16}$

As the decade progressed, other ministers inserted more human agency into this apocalyptic narrative. Baptist minister Harvey Johnson protested "the slaughter of my people, without judge or jury," which demonstrates "the white man's unfitness for self-government." Johnson quoted from a set of resolutions adopted at a mass meeting in Boston. The first resolutions condemn the "almost daily" practice of "roasting alive" black men and women. In response to this "God-defying heartlessness," the last resolution invokes the "uncompromising spirit" of the abolitionists. It cries out "in their names" to the South: "Stop this brutality." Then it warns that if lynching does not end, the "the impetuous spirit ... of John Brown" will march "into action." Proving themselves unfit for self-government, white men should heed

is Citizens of Americus, GA, in Helen Douglass (ed.), In Memoriam: Frederick Douglass (Philadelphia: J. C. Yorston \& Co., I897), I25.

${ }^{16}$ Robert A. McGuinn, The Race Problem in the Churches (Baltimore: J. F. Weishampel, I 890), I I, 59; E. K. Love, Emancipation Oration, I Jan. I891 (Augusta: Georgia Baptist Print, 1891), 3, 13, 14; Love, A Sermon on Lynch Law and Raping (5 Nov. 1893) (Augusta: Georgia Baptist Print, I894), I9. 
the warnings offered in the abolitionist spirit or face the consequences brought in the spirit of Brown, suggests Johnson. ${ }^{17}$

By the I 890 on and early I 900 s, the abolitionist-inspired jeremiad was spreading beyond sermons to speeches, articles, and novels by black activists and writers. In 1903, Robert $H$. Terrell, a black Justice of the Peace in Washington, DC, gave a speech on the anniversary of the Preliminary Proclamation. The speech narrates a history of slavery and abolition, terming the abolitionists "sublime and holy" men "whom God had raised up." He mentions Brown, explaining that he and other abolitionists set the country "aflame." Then this flame engulfed the nation, Terrell explains. The Civil War was "punishment for our country's greatest crime." Now, however, the abolitionists' struggle must continue. The Emancipation Proclamation did not fulfil their expectations, he observes, for black people suffer the "terrible outrages and unspeakable cruelties" of lynchings. Terrell ends by quoting lines from Byron: "For freedom's battle once begun, / Bequeathed from bleeding sire to son, / Though baffled oft, is ever won." The holy abolitionist warriors pass on their swords to those who would continue freedom's battle. ${ }^{18}$

Most other abolitionist awakenings in antilynching nonfiction of the early twentieth century revolved around Brown. In 1906 Kelly Miller described lynching as a crucifixion and imagined Brown's horror at the news that black people had been lynched in his old territory of "bleeding Kansas." In 1926 he added that antilynching reform required the "courage and sacrifice" of Brown, not only the "safe, constructive endeavor" of Lincoln, and recommended that black protest organizations prioritize a "militant," uncompromising, John Brown approach. In 1934, he compared Brown to Christ as a "genuine radical" and observed that America needed this kind of radical today. For Miller, Brown's emancipatory martyrdom reflected a radical, uncompromising protest model that contemporary radicals might adapt as they confronted the new crucifixions of lynch law. ${ }^{19}$

Numerous other antilynching articles and nonfiction books used Brown to prophesy another American apocalypse. Journalist Robert L. Duffus, who wrote a series of anti-Klan articles, visited Brown's grave in 1920 and imagined

${ }^{17}$ Harvey Johnson, The White Man's Failure in Government (Baltimore: Afro-American Publishing Company, 1900), 20, I4, I 5 , 16.

${ }_{18}$ Robert H. Terrell, $A$ Glance at the Past and Present of the Negro (Washington, DC: Press of R. L. Pendleton, I903), 8, 6, 4, I3, 16.

19 Kelly Miller, "An Appeal to Reason on the Race Problem" (1906), in Miller, Race Adjustment (New York: Neale Publishing Company, 1908), 57-87, 71, 82; Miller, "Race Discrimination in the District of Columbia," New York Amsterdam News, 2 June 1926, I 2; Miller, "The So-Called Negro Radicals," New York Amsterdam News, is Sept. 1934, 8. 
his response to lynching: he would remember the "oceans of blood" that he "helped to shed" and realize that even this red sea was not punishment enough. By raising Brown from his grave, to walk the earth and "hear the shrieks of the tortured victims," Duffus hints that a John Brown response to lynching might be on the horizon. A few years later, William H. Moses used Brown to prophesy holy warfare but used the imagery of Ezekiel rather than Exodus. Responding to the notion that God ignored the Middle Passage, plantation slavery, and now lynching, he explained that Brown was a holy warrior, commanded by Jehovah, who did God's work during slavery. More Browns would do His work today, Moses continued: the world still needed "its Browns," its "martyrs," and so from Brown's "bones and ashes ... will spring a multitude that will prevail." Here, Brown's execution is an altar sacrifice (that turned his body into ashes) but one from which he will be resurrected. Drawing from Ezekiel 37:10, where God brings together dry bones into a great army, Moses imagines that Brown's bones march on to fight the "powers of hell." 20

Other nonfiction articles went even further and imagined the lynch victim as an emancipatory martyr in the John Brown tradition. In October 1919, Challenge magazine described lynching as the nation shoving black people "down the hills towards Golgotha," as well as a process of reenslavement. But as America tries to crucify them (at Golgotha) and reenslave them (put them in "shackles"), they will respond with the apocalypse. Like Brown, who "cried out" on their behalf and was "armed with the sword of righteousness," African Americans must "stand at Armageddon and battle for the Lord." Rather than be crucified within the South's Biblical, Lost Cause drama, mob victims must enact Brown's drama of Revelations. ${ }^{21}$

One of the most extensive nonfiction resurrections of Brown for antilynching came in 1920, when British writer Stephen Graham travelled through the South and then published his book Children of the Slaves, retitled The Soul of John Brown for the US market. The book's biggest theme is lynching and Graham points to its religious symbolism, explaining that it satisfies a religious need. He terms the sheriffs and governors who let mobs have their way "Pilates," as though each lynching restages Calvary. The book also traces the origins of lynching to slavery. Graham dwells on the torture and violence of slavery, going on to claim that lynching is most brutal in the parts of the country where slaves were owned, because the masters' children have brutality

${ }^{20}$ Robert L. Duffus, "The Grave of Ossawatomie," The Nation, I4 Feb. 1920, I99; "Darrow and Moses in Big Debate on Negro Religion," Pittsburgh Courier, 24 Jan. I93 I, A 10.

21 "Let Us Stand at Armageddon and Battle for the Lord," Challenge, Oct. 1919, in Robert T. Kerlin (ed.), The Voice of the Negro, IgIg (New York: E. P. Dutton, I920), I9. 
in their blood. White southerners "crave to see Uncle Tom's flesh crackling in the flames" because "[ $t$ ]heir fathers did," explains Graham. ${ }^{22}$

Against the ritual burning of Uncle Tom, Graham positions John Brown, whose marching soul is "the march of the cause of humanity as a whole." But if a martyr for humanity, Brown is a messianic, emancipatory martyr. His raid and death prophesied the war, Graham explains. Those who saw him executed felt a "premonitory terror" and "soon came the great war" which Graham describes, like many antilynching writers, as "the wrath of God." This means that the solution to lynching might be wrath too. Graham quotes Brown's last letter, about crimes purged in blood, and asks, "Could not the lesson be learned?" He prophesies that if America does not cast out the "devil," it will "again be ravished by the Angel of Death." Then Graham ends his book with a vision of Brown reappearing to find lynch mobs burning "the children of slaves," and a warning that Brown's "soul goes marching on" and is "still the soul of vengeance and wrath." Countering the religious ritual of lynching and its reversal of emancipation, Graham's antilynching jeremiad summons Brown's vengeful and emancipatory soul. ${ }^{23}$

In the realm of fiction, two writers raised Brown's specter over their lynching performances. In James Weldon Johnson's The Autobiography of an Excolored Man (1912), the narrator attends two performances in a single night, one after the other. The first is a "big meeting" led by a preacher named John Brown. Everything about his sermon is theatrical, from the rhythms of his speech to his "highly and effectively dramatic" march up and down the pulpit platform. This performance, Johnson hints, remembers the abolitionist John Brown's performance of biblical doctrine during his raid, trial and execution. The preacher not only shares the abolitionist's name and leads his congregation in a "heavenly march" (echoing the famous lines from the song "John Brown's Body"), he also has "the intuition of a born theatrical manager." Here the narrator quotes Thoreau's famous lines about Brown from July i 860 ("no theatrical manager could have arranged things so wisely to give effect to his behavior and words"). Further directing the reader's attention to the presence of abolitionist memory in this scene, the narrator observes of the congregation's call-and-response that "slave music" will become a "treasured heritage" of black Americans. ${ }^{24}$

22 Stephen Graham, Children of the Slaves (London: Macmillan, 1920), 247, 20.

${ }^{23}$ Ibid., 170, 1 8, 259, 260, 304, 305.

${ }^{24}$ James Weldon Johnson, The Autobiography of an Ex-colored Man (1912), in Sondra Kathryn Wilson (ed.), The Selected Writings of James Weldon Johnson, Volume II (New York: Oxford University Press, 1995), 273-362, 346, 347, 349. 
Then a lynching takes place. It too is a performance, put together "in quite an orderly manner." The narrator is an unwilling audience for this second performance of the night. He feels himself "fixed to the spot" and powerless to look away as southern whites play at "chivalry and bravery and justice." Seen as theater, the performance makes sense, observes the narrator, for intelligent men attend theatrical performances and "applaud the impossible hero, who with his single sword slays everybody." Staged one after the other, the two performances (sermon and lynching) form their own call-and-response. John Brown, the "theatrical manager," completes a black performance of faith just as the lynchers, compared to actors in a play, begin their performance of justice. The lynching appears in the novel as a response to the black performance of faith, with its embedded memory of martyrdom: the abolitionist martyr Brown marches beside the black preacher and the lynchers answer this performance of martyrdom with their own performance of blood sacrifice. ${ }^{25}$

Another novel that restaged John Brown's martyrdom did so more explicitly. Walter White's The Fire in the Flint (1924) describes white supremacy as a religion (a "faith" that holds its white-supremacist leaders up as "gods") and lynching as a form of slavery ("in many respects more oppressive than the pre-Civil War variety"). It offers its central character, Kenneth Harper, as an abolitionist-inspired martyr for antilynching. Kenneth thinks of emancipation as "that which was called freedom" - the Proclamation may have ended legal slavery but it did not bring liberty. Observing how white supremacists maintain the slave system, he notes that they use religious rituals and dramatic performance. They hold meetings in a natural amphitheater, perform mysterious ceremonies, tell stories of their exploits with as much "drama" as possible, and behave as though they are part of a "sacred order." But as he seeks to remove the shackles that imprison southern black people - especially in the form of lynch ropes-Kenneth observes religious counterperformances. He falls in love with a woman as she performs a slave spiritual ("born in the dark days of slavery") and realizes that a black church service is a "theatric performance" of the same faith that inspired slaves (guiding them through "the dark days of slavery"). Like lynching, these religious performances are memory performances. Even as the lynching ritual reestablishes slavery, spirituals and church services remember slave resistance. ${ }^{26}$

After witnessing these counterperformances, Kenneth wonders if today's black southerners might need a "twentieth-century Moses" to lead them

25 Ibid., 35 I, 352.

26 Walter White, The Fire in the Flint (New York: Knopf, 1924), 38, 91, 48, I 2 I, I 22, I 24, I 27, 80, 90 . 
from bondage again. He decides this will be him. As he starts to organize cooperative societies, his understanding of his role shifts to the New Testament: he thinks of himself as a "latter-day disciple bringing a new solution and a new hope to his people." In his role as a biblical leader, he realizes the importance of embracing both theater and memory. He knows his movement will need some "show and pomp" to counter the KKK's "ceremony and dress," and he tells his members that they must fight against the attempt to turn them into "slaves." Then the movement's first martyrdom takes place. Bob, Kenneth's brother, is marked for martyrdom when his eyes shine like Joan of Arc's. Soon after this moment, a lynch mob attacks him. As he flees, Bob remembers fugitive slave hunts. Slaves used to wade through water to escape bloodhounds, he remembers, and so he does the same. The memory performance ends in a martyrdom. Bob kills himself before the mob catches him and lies with his arms spread wide in a crucifixion pose. ${ }^{27}$

The mob burns Bob's body anyway and manages to enjoy the "show." Meanwhile, Kenneth has decided that the movement needs another "martyr" to its "moral cause." It needs a "meteor-like John Brown," he thinks (echoing numerous descriptions from the $\mathrm{i} 860 \mathrm{0}$ of Brown as meteor). From his role as a biblical leader (Moses and the disciples), Kenneth now shifts to the role of emancipatory martyr: "bursting into brilliance born of indignation," Brown died "gloriously for [his] cause," and today's cause needs another "latterday Crusader." Perhaps his death, like Brown's, will stir "the spirit of revolt ... even higher," he thinks. Within this biblical, abolitionist-inspired drama he views white southerners as "Pontius Pilates" and himself as a Christ figure. Once he hears news of his brother's death, Kenneth knows "his Gethsemane" has begun. Though Bob remembers fugitive slaves and dies in a Christ-like posture, Kenneth will remember the abolitionists and perform an even more self-conscious martyrdom. He imagines possible scenes, with himself playing "the leading role" and performing magnificently. He would be like "great actors on stage," his "acting" a "wonder." Minutes later, a mob of fifteen people attacks and kills him. Though the novel ends by replaying the lynching from a white perspective (a newspaper article claims that Kenneth confessed to attacking a white woman and was killed by a mob of five thousand), Kenneth's anticipation of his martyrdom moment means that the novel's readers are primed to look past this newspaper narrative and see his death as a fulfilment of prophecy and a Brown-esque catalyst for revolt. It is a brief display of the fire in the flint, which "shows not till it is struck" (as the proverb, from which White takes his title and epigraph, proclaims).

27 Ibid., 91, 145, 176, 179, 193, 233. 
Beneath the flint, between the lines of the newspaper report, is the fire of a "meteor-like" martyr who bursts briefly into brilliance. ${ }^{28}$

John Brown himself would have been surprised by his frequent presence in antilynching protest literature and the endurance of the emancipatory martyr symbol that he had inaugurated in his prison letters. His last letter had expressed doubt as to the power of protest writing, proclaiming that the nation's crimes could only be purged away in blood. He was not the only abolitionist to conclude that blood would trump ink. Brown's last words echoed a letter by Theodore Parker, written a week earlier, on 24 November i 859: "A few years ago, it did not seem difficult first to check slavery, and then to end it, without any bloodshed," wrote Parker to fellow abolitionist Francis Jackson. "I think this cannot be done now ... All the great charters of humanity have been writ in blood. I once hoped that American democracy would be engrossed in less costly ink." Sure enough, the "costly ink" of blood wrote slavery's next chapter. Armed conflict continued the process of emancipation that pen and paper had begun. Then America went on to write the post-emancipation story in the blood of lynchings. Yet the "charter of humanity" was writ in ink as well as blood: as John Brown's body lay moldering in the grave, his words marched on to become a living protest legacy. ${ }^{29}$

${ }^{28}$ Ibid., 237, 246, 247, 258, 263, 272, 289-90, 292, 293.

29 Parker in Stauffer and Trodd, 135. 